\title{
Curcumin preserves cognitive function and improve serum HDL in chronic cerebral hypoperfusion aging-rats
}

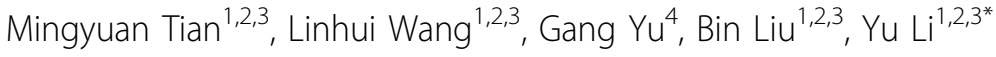 \\ From 2011 International Conference on Molecular Neurodegeneration \\ Shanghai, China. 22-24 September 2011
}

\section{Background}

Chronic cerebral hypoperfusion is believed to be a critical factor on the occurrence of $\mathrm{AD}$ and $\mathrm{VaD}$ for which there is no effective therapy currently. It has been reported that high levels of circulating high density lipoprotein (HDL) can reduce the risk of cardiovascular disease. Although the relationship between cognitive function and serum lipids has captured attention, previous studies have shown ambiguous results. We investigated the effects of Curcumin on cognitive impairment and serum HDL levels and investigated whether increasing serum HDL levels ameliorate VAD-like cognitive deficits in rats induced by permanent occlusion of bilateral common carotid arteries (2VO).

\section{Method}

Male Sprague-Dawley rats were subjected to permanent occlusion of bilateral common carotid arteries (2VO) to produce chronic cerebral ischemia. Animals were randomly divided into 5 groups: normal control group, shamoperated group, $2 \mathrm{VO}$ group, $2 \mathrm{VO}+\mathrm{Curcumin} 100 \mathrm{mg} / \mathrm{kg}$ group, $2 \mathrm{VO}+\mathrm{Curcumin} 50 \mathrm{mg} / \mathrm{kg}$ group. Low doses of Curcumin $(50 \mathrm{mg} / \mathrm{kg}$ ) or high doses of Curcumin $(100 \mathrm{mg} /$ $\mathrm{kg}$ ) were dissolved in DMSO. All animals were injected intraperitoneally with DMSO solution of Curcumin or a same volume of normal DMSO after surgery. Each group was injected once daily for four consecutive weeks. The spatial learning capacity and cognitive function of these animals was assessed in the Morris water maze 30 days after the onset of $2 \mathrm{VO}$. Serum concentrations of high-density lipoprotein (HDL) were measured. Associations between serum concentrations of HDL and cognitive function were investigated for each group.

\section{Result}

Morris water maze for spatial orientation abilities showed that rats in 2VO group develop impaired learning and cognitive deficits, injection intraperitoneally of Curcumin can attenuate cognitive impairment $(\mathrm{P}<0.05)$. $2 \mathrm{VO}+\mathrm{Curcumin}$ group had higher serum HDL cholesterol levels than that of $2 \mathrm{VO}$ group $(\mathrm{P}<0.05)$. No significant differences were found in the serum level of HDL among $2 \mathrm{VO}+\mathrm{Curcumin}$ group rats, sham-operated group rats and normal control group rats. Further more, plasma HDL levels correlated significantly with cognitive function.

\section{Conclusion}

Our findings suggest that Curcumin have a protective influence on cognitive function and apparently increase serum HDL in $2 \mathrm{VO}$ group rats. Furthermore, serum HDL levels have positive association with cognitive function. The relation between Curcumin and HDL is hoped for new preventive and therapeutic strategies for cognitive deficits.

\section{Acknowledgements \\ This study was supported by Program for Excellent talent in University of Chongqing (2010).}

\section{Author details}

'Department of Pathology, Chongqing Medical University, Chongqing 400016, China. ${ }^{2}$ Institute of Neuroscience, Chongqing Medical University, Chongqing 400016, China. ${ }^{3}$ Chongqing Key Laboratory of Neurobiology, Chongqing Medical University, Chongqing 400016, China. ${ }^{4}$ Department of Neurology, The First Affiliated Hospital, Chongqing Medical University, Chongqing 400016, China. 
doi:10.1186/1750-1326-7-S1-S3

Cite this article as: Tian et al:: Curcumin preserves cognitive function and improve serum HDL in chronic cerebral hypoperfusion aging-rats. Molecular Neurodegeneration 2012 7(Suppl 1):S3.

Submit your next manuscript to BioMed Central and take full advantage of:

- Convenient online submission

- Thorough peer review

- No space constraints or color figure charges

- Immediate publication on acceptance

- Inclusion in PubMed, CAS, Scopus and Google Scholar

- Research which is freely available for redistribution 